\title{
Corticotropin-releasing hormone signals adversity in both the placenta and the brain: regulation by glucocorticoids and allostatic overload
}

\author{
J Schulkin \\ Department of Research, American College of Obstetricians and Gynecologists, Department of Physiology and Biophysics, Georgetown University, \\ Washington DC, USA \\ (Requests for offprints should be addressed to J Schulkin, Department of Research, American College of Obstetricians and Gynecologists, 409 12th Street SW, \\ Washington DC, 20024-2188, USA)
}

\begin{abstract}
Glucocorticoids regulate corticotropin-releasing hormone $(\mathrm{CRH})$ gene expression in the placenta and the brain. In both the placenta and two extrahypothalamic sites in the brain (the amygdala and the bed nucleus of the stria terminalis), glucocorticoids elevate CRH gene expression. One functional role of the elevation of CRH by glucocorticoids may be to signal adversity. When CRH is over-expressed in the placenta, it may indicate that the
\end{abstract}

pregnancy is in danger, and preterm labor may result. When CRH is over-expressed in the brains of animals, they may become more fearful. Both situations possibly reflect allostatic mechanisms and vulnerability to allostatic overload, a condition in which biological tissue may be compromised.

Journal of Endocrinology (1999) 161, 349-356

\section{Introduction}

Preterm delivery accounts for up to $11 \%$ of all births and is a leading factor in neonatal morbidity; consequences of preterm birth include low birth weight and decreased respiratory function (Center for Disease Control 1997). Several physiological systems linked to the placenta may play a role in preterm labor (see e.g. Goland et al. 1992, MacGregor et al. 1995, Pepe \& Albrecht 1995).

A large number of hormones are produced in the placenta. The list includes but is not limited to: corticotropin-releasing hormone $(\mathrm{CRH})$, urocortin, adrenocorticotropin $(\mathrm{ACTH})$, angiotensin, atrial natriuretic factor, prolactin, oxytocin, cytokines, gonadotropin releasing hormone, opioids, somatostatin, prostaglandin and parathyroid hormone (see e.g. Taniguchi et al. 1991, Ahmed et al. 1992, Lefebvre et al. 1992, Bramley et al. 1994, Lim \& Gude 1995, Petraglia et al. 1990a, 1996). These placental peptides are homologous in structure to those in the fetal and in the mature brain (Challis et al. 1995).

The hypothesis in this review is that $\mathrm{CRH}$ is elevated during adverse events in pregnancy, that it may be a predictor of preterm labor when there are conditions of adversity (see e.g. Wolfe et al. 1988b, Goland et al. 1993), and that it is altered in the brain when we experience fear and anxiety (Gold et al. 1984, Nemeroff et al. 1984, Nemeroff 1992), or a sense of potential harm (Kalin et al. 1989, Koob 1993, Schulkin et al. 1994). In the case of adverse events in pregnancy, CRH may be over-expressed in the placenta; in the case of fear and anxiety, CRH may be over-expressed in the brain.

\section{Expression of corticotropin-releasing hormone in the placenta}

The activation of the fetal hypothalamic-pituitary-adrenal axis promotes the maturation of the fetus and parturition (Challis et al. 1995). CRH is a peptide hormone which was originally discovered in the paraventricular nucleus of the hypothalamus and which is fundamental to the regulation of pituitary secretion of ACTH (Vale et al. 1981). $\mathrm{CRH}$ was subsequently isolated in the placenta, and found to be identical to $\mathrm{CRH}$ in the hypothalamus (Shibasaki et al. 1982), and in extrahypothalamic sites in the brain (Swanson et al. 1983). In placental tissue, CRH is largely localized in syncytiotrophoblast and intermediate trophoblast cell bodies (see e.g. Firn et al. 1988; F Petraglia \& P Sawchenko, unpublished data) (Fig. 1). 


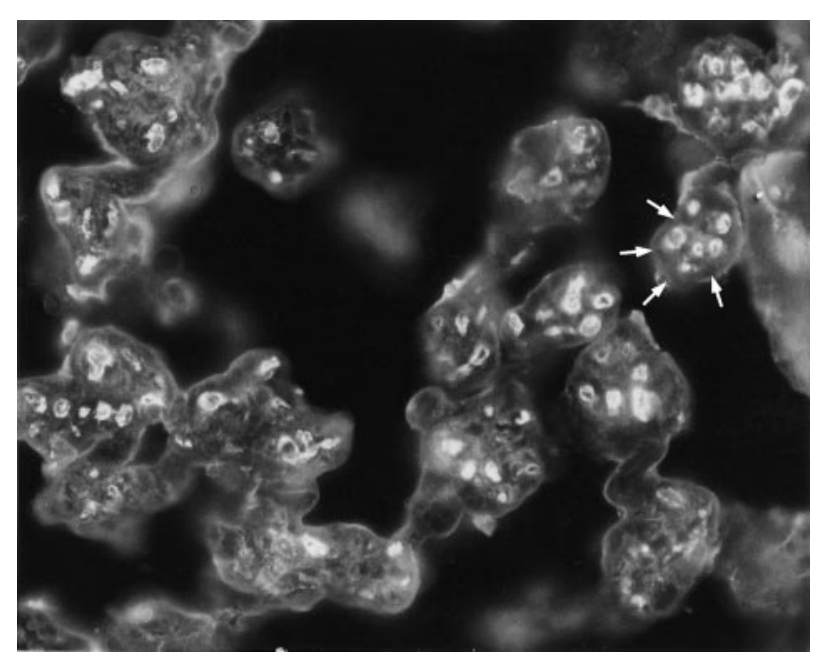

Figure 1 Corticotropin-releasing hormone immunostaining in the human placenta (arrows) (courtesy of F Petraglia and P Sawchenko).

$\mathrm{CRH}$ in humans is not detectable in plasma except during pregnancy (Sasaki et al. 1984, Cambell et al. 1987, Goland et al. 1988, Wolfe et al. 1988a). In the second and third trimesters of normal pregnancy, $\mathrm{CRH}$ is elevated in maternal plasma that is derived from the placenta (Fig. 2). At the same time, both fetal and maternal ACTH and cortisol levels are elevated (Challis et al. 1995, Goland et al. 1995). Following parturition, CRH levels in the plasma rapidly decrease to nadir levels (Laatikainen et al. 1987). In other words, CRH gene expression in placental trophoblast cells rises towards the end of pregnancy in several species, including humans (Firn et al. 1988, Riley et al. 1991), gorillas (Robinson et al. 1989), and rhesus monkeys (Wu et al. 1995), although there appear to be species in which this is not the case (e.g. baboons; Goland et al. 1992, Smith et al. 1993).

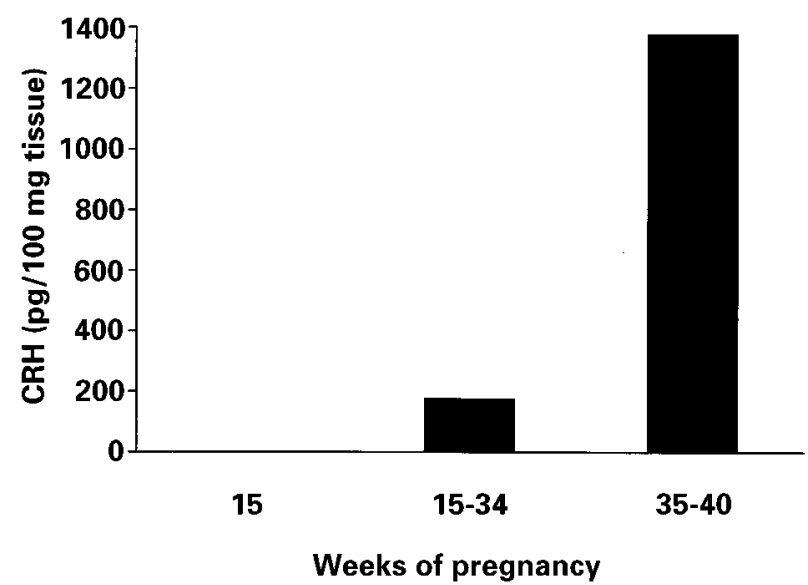

Figure 2 Concentration of corticotropin-releasing hormone in placental tissue at various stages of human gestation (adapted from Firn et al. 1988).

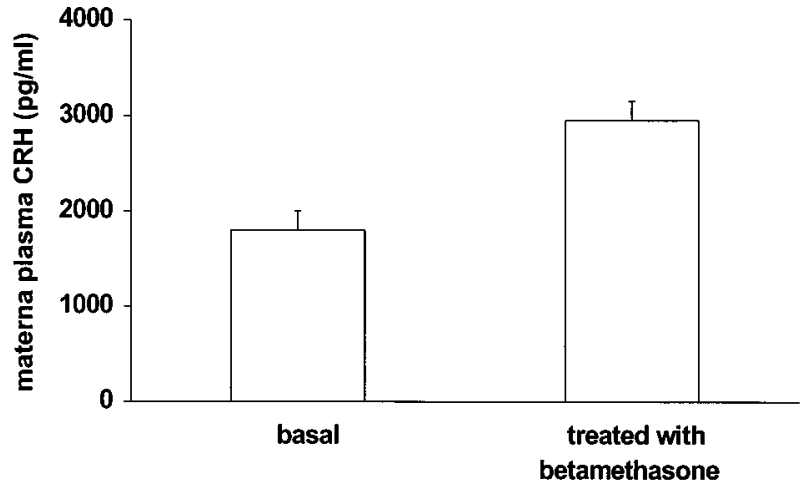

Figure 3 Maternal plasma levels of corticotropin-releasing hormone in pregnant women at 30 to 35 weeks' gestation receiving betamethasone and in control patients (basal) (adapted from Marinoni et al. 1998).

\section{Regulation of CRH by glucocorticoids}

Classically, glucocorticoids are known to restrain $\mathrm{CRH}$ production by negative feedback (Munck et al. 1984) but, importantly, in one early study it was reported that dexamethasone treatment did not suppress levels of $\mathrm{CRH}$ in the plasma of pregnant women (Tropper et al. 1987). It was then demonstrated that glucocorticoids do not inhibit the production of $\mathrm{CRH}$ in the placenta as expected; rather, they increase CRH gene expression in the placenta (Robinson et al. 1988, Jones et al. 1989). Glucocorticoids increase $\mathrm{CRH}$ gene expression in primary cultures of human placental trophoblasts. These effects are dose related, and may be greater in response to dexamethasone than for cortisol, suggesting that these effects are dependent upon type II glucocorticoid receptor sites (Jones et al. 1989, Challis et al. 1995). Moreover, a recent study demonstrated that pregnant women treated with betamethasone after 30 weeks gestation had increased $\mathrm{CRH}$ levels in both plasma and placental tissue (Marinoni et al. 1998) (Fig. 3). An additional study also revealed that pregnant patients at 24 weeks also have increased levels of plasma $\mathrm{CRH}$ following betamethasone treatment (Korebrits et al. 1998). Thus, in marked contrast to glucocorticoids' well known inhibition of CRH via type II glucocorticoid receptor sites at the level of the paraventricular nucleus of the hypothalamus, and the negative restraint of the hypothalamic-pituitary-adrenal axis (Munck et al. 1984, Sawchenko 1987, Swanson \& Simmons 1989), glucocorticoids increase CRH gene expression in the placenta.

\section{Placental CRH expression under duress}

The most consistent fact about CRH detected in plasma in pregnant women is its link to both potential maternal-fetal distress, or greater metabolic and physiological demands, in women who go on to experience preterm labor (Wolfe 


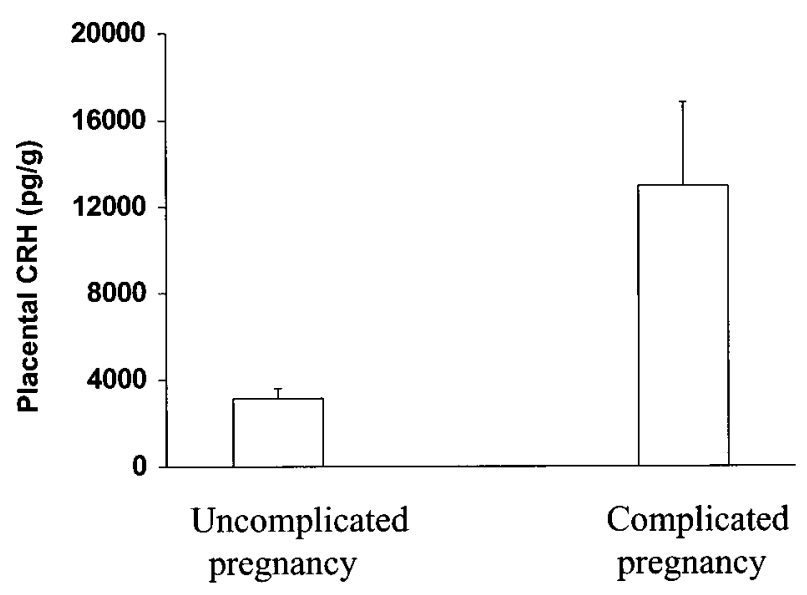

Figure 4 Human placental corticotropin-releasing hormone peptide content in pregnancies complicated by pre-eclampsia and in uncomplicated pregnancies (adapted from Goland et al. 1995).

et al. 1988b, Warren et al. 1992, Berkowitz et al. 1996). For example, CRH and glucocorticoid levels are increased following bacterial infectious diseases (Petraglia et al. 1995), pre-eclampsia (Goland et al. 1995), diabetes (Wolfe et al. 1988b), growth retarded fetal development (Goland et al. 1993), multiple gestation (Wolfe et al. 1988b), and psychosocial stress (Hobel et al. 1999) (Fig. 4). In other words, for conditions of adversity, or great metabolic demand, CRH may play an important role in parturition, and in some instances may predict vulnerability to preterm delivery (c.f. McLean et al. 1995, Berokowitz et al. 1996, Bisits et al. 1998).

\section{CRH and parturition}

Oxytocin and prostaglandin, linked to parturition, enhance CRH gene expression in placental tissue (Petraglia et al. 1989). Bacterial microbial induced cytokine production may facilitate parturition via changes in $\mathrm{CRH}$; there is a well established link between cytokine production, the release of CRH (Chrousos 1996) and a reduction in reproductive fitness (Ferin 1995).

Decreases in progesterone levels lead to the upregulation of $\mathrm{CRH}$ in the placenta, perhaps by enhanced binding of glucocorticoids (Karalis et al. 1996). In addition, decreases in $\mathrm{CRH}$ binding protein are linked to the upregulation of CRH (Behan et al. 1996). Finally, a recent study found that a CRH type I receptor antagonist can delay parturition in sheep (Chan et al. 1998).

Clearly, there is more than one mechanism to facilitate an event as important as birth-after all, the end-point of evolution is successful reproduction. For example, estrogen is known to increase oxytocin gene expression in the placenta, which facilitates the onset of labor. An important point is that the steroid is sustaining or increasing the peptide, which then contributes to the onset of parturition.
In general, steroids act to regulate peptides (see e.g. Pfaff 1980, Petraglia et al. 1990b, Herbert 1993, Schulkin 1998). In the placenta, glucocorticoids increase $\mathrm{CRH}$ expression. What seems clear about $\mathrm{CRH}$ is its overexpression by the placenta under adverse pregnancy conditions, which might reflect allostatic regulation and allostatic overload.

\section{Allostasis and allostatic overload}

The concept of allostasis is tied to systems in which there is no clear physiological set point. That is, the set point is fluid and changing (Sterling \& Eyer 1988). Allostasis refers to the ability to achieve stability through change. Whereas homeostatic systems such as blood oxygen, blood $\mathrm{pH}$, and body temperature must be maintained within a narrow range, allostatic systems are more labile, allowing them to adjust to external and internal circumstances (McEwen \& Stellar 1993). Both homeostatic (Bernard 1865; Cannon 1932, Richter 1943) and allostatic regulation help maintain the internal milieu (Sterling \& Eyer 1988, Schulkin et al. 1994, 1998, McEwen 1998). It is the latter concept that we hypothesize has relevance to understanding the endocrine mechanisms that may underlie preterm labor induced by maternal-fetal distress.

Allostatic responses, within limits, may prove adaptive and protective. Hormones such as $\mathrm{CRH}$ or cortisol can be destructive when they are activated for long periods of time, or when the body is unable to stop producing them (Sapolsky 1992, McEwen 1998). Glucocorticoids, such as cortisol, restrain hormone production by inhibiting $\mathrm{CRH}$ gene expression in the paraventricular nucleus of the hypothalamus (see e.g. Munck et al. 1984, Sawchenko 1987). In this context, the event is protective. If high cortisol levels continue to persist, it may be destructive (e.g. bone demineralization, immune defense degradation). Biological tissue is compromised when pushed beyond its limits. The $\mathrm{CRH}$ that is hypersecreted in pregnant women following situations of bacterial infectious diseases, pre-eclampsia or hypertension, multiple gestations, and psychosocial stress may be conditions of allostatic overload. Under conditions of allostatic overload, parturition may be adaptive to both mother and fetus, by both reducing stress on the pregnant woman and removing the fetus from an over-stressed environment.

\section{Expression of $\mathrm{CRH}$ in the brain}

Corticotropin-releasing hormone and binding protein are widely distributed in the central nervous system (see e.g. Swanson et al. 1983, Sawchenko 1993, Behan et al. 1996, Gray \& Birnaman 1996). In addition to the paraventricular nucleus and lateral region of the hypothalamus, $\mathrm{CRH}$ is found in the frontal cortex and regions of the thalamus, as well as brainstem regions near the locus coeruleus 

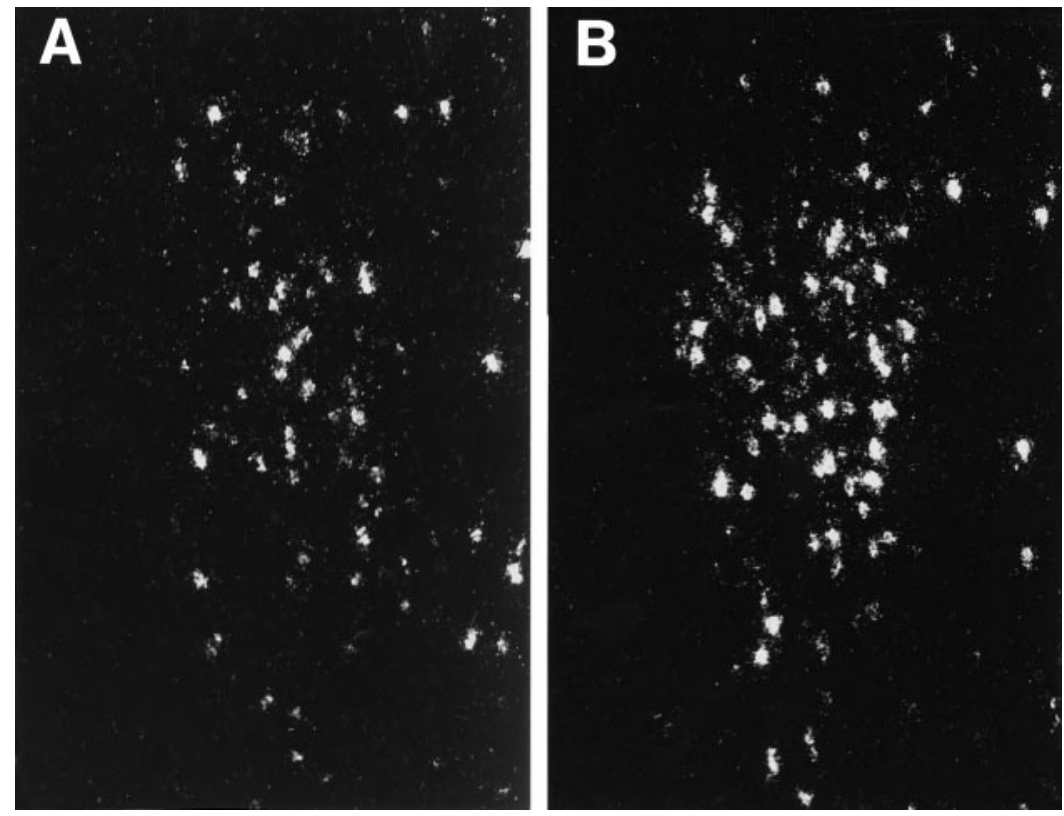

Figure 5 Corticotropin-releasing hormone gene expression in the lateral bed nucleus of the stria terminalis in $(B)$ rats treated with corticosterone and $(A)$ those that were untreated (from Makino et al. 1994b).

(Valentino et al. 1992). At least two CRH receptors sites are found in the brain (Potter et al. 1994, Lovenberg et al. 1995).

Two regions in which CRH is particularly conspicuous are in the central nucleus of the amygdala and the lateral bed nucleus of the stria terminalis (Ju et al. 1989, Moga et al. 1989, Makino et al. 1994b). Both regions are known to influence the regulation of the hypothalamic-pituitaryadrenal axis (Herman \& Cullian 1997). The lateral bed nucleus of the stria terminalis is particularly important in regulating $\mathrm{CRH}$ gene expression in the paraventricular nucleus of the hypothalamus under a number of conditions (Herman \& Cullian 1997). The bed nucleus of the stria terminalis (e.g. extended amygdala) is ideally situated to regulate the paraventricular nucleus, because of the massive anatomical connectivity between these two regions (Alheid et al. 1996).

\section{Regulation of CRH by glucocorticoids}

Importantly, $\mathrm{CRH}$ gene expression is differentially regulated in the brain by glucocorticoid hormones (Swanson \& Simmons 1989, Imaki et al. 1991, Tanimura \& Watts 1998). In the parvocellular region of the paraventricular nucleus, glucocorticoid activation decreases $\mathrm{CRH}$ gene expression, while in the central nucleus of the amygdala and lateral bed nucleus of the stria terminalis, $\mathrm{CRH}$ gene expression is enhanced by glucocorticoids (Swanson \& Simmons 1989, Makino et al. 1994a,b, Watts \& SanchezWatts 1995, Watts 1996) (Fig. 5). These effects on the upregulation of $\mathrm{CRH}$ gene expression may be mediated by both type I and type II glucocorticoid receptor sites (Watts \& Sanchez-Watts 1995, Tanimura \& Watts 1998).

Corticotropin-releasing hormone regulation by negative feedback is not axiomatic even at the level of the paraventricular nucleus (Swanson \& Simmons 1989, Tanimura \& Watts 1998). Interestingly, under various conditions, glucocorticoids in the paraventricular nucleus of the hypothalamus stop inhibiting CRH gene expression (Pich et al. 1993a, Kalin et al. 1994, Albeck et al. 1997, Tanimura \& Watts 1998). These findings at the level of the paraventricular nucleus suggest a breakdown of normal regulatory function and, together with the elevated levels of $\mathrm{CRH}$ gene expression in the central nucleus of the amygdala and lateral bed nucleus of the stria terminalis, may reflect allostatic overload (Schulkin et al. 1998). Consistent with this, CRH is elevated in the cerebrospinal fluid, together with elevated systemic levels of cortisol, in people who are chronically fearful/anxious and depressed (Nemeroff et al. 1984, Gold et al. 1988, Kling et al. 1993, Nemeroff 1992). This condition is also one in which there is a vulnerability to bone loss (Michelson et al. 1996), or hippocampal deterioration (Sheline et al. 1996), which are perhaps also examples of allostatic overload (McEwen 1998).

\section{Behavioral effects of elevated CRH}

Elevated levels of CRH (Koob \& Bloom 1985) in specific regions of the brain that include the central nucleus of the 
amygdala and the lateral bed nucleus of the stria terminalis increase the likelihood that an event will be perceived as dangerous (see e.g. Koob 1993, Kalin et al. 1994, Lee \& Davis 1997). These two neural sites underlie the behavioral response to fear and anxiety (LeDoux 1987, 1996, Rosen \& Schulkin 1998).

Transgenic mice with overexpression of $\mathrm{CRH}$ in the brain demonstrate exaggerated fear responses (StenzelPoore et al. 1994). Fear responses are attenuated by central pharmacological blockade of CRH expression (Swerdlow et al. 1989, Koob 1993), but not peripheral blockade of CRH expression (Pich et al. 1993b). In particular, antagonists of $\mathrm{CRH}$ directed at the central nucleus of the amygdala reduce a number of fear-induced behavioral responses (Swerdlow et al. 1989, Koob 1993). Infusion of $\mathrm{CRH}$ directly into the lateral or third ventricle (e.g. Koob 1993) or the bed nucleus of the stria terminalis (extended amygdala) facilitates fear responses (Lee \& Davis 1997).

Interestingly, it has been suggested that pharmacological blockade of type I CRH receptor sites reduces fear-related behavioral responses (Deak et al. 1999) and, perhaps together with decreased levels of central $\mathrm{CRH}$ binding protein, facilitates the binding of $\mathrm{CRH}$ and the expression of fear. It should also be remembered that the type I CRH receptor antagonist has been reported to delay parturition (Chan et al. 1998).

Animal studies suggest that excessive prenatal stress and fear can have long term impact on the offspring (Weinstock 1996). One study, for example, has shown that aversive stress results in elevated cortisol levels in both the mother and the fetus(es). When sacrificed as young adults, the offspring demonstrate increased levels of CRH (49\%) in the central nucleus of the amygdala compared with control rats. Prenatal stress experiences can increase fear responses when these animals are provoked as adults (Cratty et al. 1995). Consistent with this picture are the experiments demonstrating that $\mathrm{CRH}$ injections during pregnancy in rats increase the vocalization of the offspring when tested in isolation chambers during ontogeny (Williams et al. 1995).

Glucocorticoid and CRH elevation decrease reproductive fitness and decrease sexual behavior (e.g. Nappi \& Rivier 1995). When glucocorticoids are elevated under duress, testosterone or estrogen is reduced in most species that have been studied (Sapolsky 1992). The state of combating disease or experiencing fear (or psychological stress) are metabolically expensive events, and thereby reduce the hormones of reproduction and the likelihood of successful reproduction (Wasser 1996). Interestingly, in experiments in which there is elevated estrogen there is decreased $\mathrm{CRH}$ expression in the brain (Patchev \& Almeida 1996).

Importantly, rather than restraining behavioral effects, glucocorticoids, via central activation of $\mathrm{CRH}$, enhance these effects (Schulkin et al. 1998). For example, glucocorticoids facilitate CRH-induced fear responses (Lee et al.

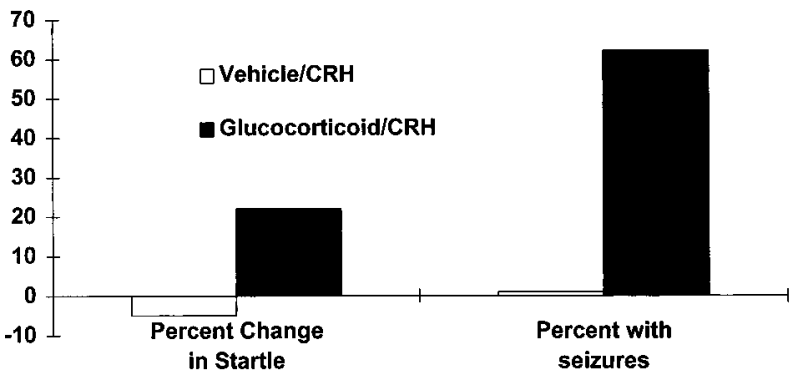

Figure 6 Potentiation of glucocorticoids on corticotropin-releasing hormone-related startle reactions and seizures (adapted from Lee et al. 1994, Rosen et al. 1994).

1994). Rats treated with glucocorticoids systemically have increased fear-related startle responses to central CRH infusions.

When given centrally high doses of $\mathrm{CRH}$ also facilitate the vulnerability to seizures (Weiss et al. 1986). This event is linked to the activation of the amygdala (Weiss et al. 1986, Helfer et al. 1996). While it was hypothesized that glucocorticoids should restrain CRH-related seizures, we found that glucocorticoids facilitated the onset of $\mathrm{CRH}-$ induced seizures (Rosen et al. 1994) (Fig. 6). Moreover, we also found that, rather than restraining cocaineinduced seizures, which are linked to $\mathrm{CRH}$ expression in the amygdala, glucocorticoids actually increase them (Kling et al. 1993).

\section{Conclusion}

The underlying hypothesis is that $\mathrm{CRH}$ is a signal of danger in both the placenta and the brain. In one context, the impact of elevated glucocorticoids on $\mathrm{CRH}$ gene expression may render women more vulnerable to preterm labor. In the other context, glucocorticoids facilitate the perception of danger. Glucocorticoids act to magnify and sustain the CRH signal.

Glucocorticoid regulation of $\mathrm{CRH}$ gene expression in the placenta and in the amygdala and bed nucleus of the stria terminalis look remarkably similar. While glucocorticoids restrain $\mathrm{CRH}$ gene expression in the parvocellular region of the paraventricular nucleus of the hypothalamus, they magnify the effects of CRH in these other areas. This induction of CRH gene expression under certain conditions may contribute to regulatory or allostatic overload.

It should be noted that we do not know whether the mechanisms that underlie the placental increase of $\mathrm{CRH}$ by glucocorticoids are the same for both the brain and the placenta. Nor do we know whether the induction of $\mathrm{CRH}$ gene expression in the placenta originates with the mother, the fetus, or even the placenta itself. What is clear, however, is that, contrary to the belief that glucocorticoids 
always react to restrain the expression of $\mathrm{CRH}$, glucocorticoids facilitate $\mathrm{CRH}$ expression in the placenta and in regions of the brain that underlie the experience of adversity, and it is this $\mathrm{CRH}$ expression that may be significant in preterm labor (e.g. allostatic overload) at the level of the placenta, and in the brain to sustain the experience of adversity.

\section{References}

Ahmed MS, Cemerkic B \& Aghas A 1992 Properties and functions of human placental opioid system. Life Sciences 50 83-97.

Albeck DS, McKittrick CR, Blanchard DC, Blanchard RJ, Nikulina J, McEwen BS \& Sakai RR 1997 Chronic social stress alters levels of corticotropin-releasing factor and arginine vasopressin mRNA in rat brain. Journal of Neuroscience 17 4895-4903.

Alheid GF, deOlmos J \& Beltramino CA 1996 Amygdala and extended amygdala. In The Rat Nervous System, edn 2. Ed G Paxinos. San Diego: Academic Press.

Behan DP, Grigoridalis DE, Lovenberg T, Chalmers D, Heinrichs S, Liaw C \& DeSouza EB 1996 Neurobiology of corticotropin releasing factor (CRF) receptors and CRF-binding protein: implications for the treatment for CNS disorders. Molecular Psychiatry $1265-277$.

Berkowitz GS, Lapinski RH, Lockwood CJ, Florio P, BlackmorePrince C \& Petraglia F 1996 Corticotropin-releasing factor and its binding protein: maternal serum levels in term and preterm deliveries. American Journal of Obstetrics and Gynecology 174 1477-1483.

Bernard C 1865 An Introduction to the Study of Experimental Medicine. 1957 edn. New York: Dover Press.

Bisits A, Madsen G, McLean M, O'Callaghan S, Smith R \& Giles W 1998 Corticotropin-releasing hormone: a biochemical predictor of preterm delivery in a pilot randomized trial of the treatment of preterm labor. American Journal of Obstetrics and Gynecology 178 862-866.

Bramley TA, McPhie CA \& Menzies GS 1994 Human placental gonadotrophin-releasing hormone $(\mathrm{GnRH})$ binding sites. III Changes in GnRH binding levels with stage of gestation. Placenta 15 733-745.

Cambell EA, Linton EA, Wolfe CDA, Scraggs PR, Jones MT \& Lowry PJ 1987 Plasma corticotropin releasing hormone concentrations during pregnancy and parturition. Journal of Clinical Endocrinology and Metabolism 64 1054-1059.

Cannon WB 1932 The Wisdom of the Body. New York: Norton Press.

Center for Disease Control 1997 Report of final statistics 4680 (Table 44).

Challis JRG, Matthews SG, VanMeir C \& Ramirez MM 1995 Current topic: the placental corticotropin-releasing hormoneadrenocorticotropin axis. Placenta 16 481-502.

Chan EC, Falconer J, Madsen G, Rice K, Webster E, Chrousos GP \& Smith R 1998 Corticotropin-releasing hormone type I reeptor antagonist delays parturition in sheep. Endocrinology 139 3357-3360.

Chrousos GP 1996 The hypothalamic-pituitary-adrenal axis and immunomediated inflammation. New England Journal of Medicine 332 $1351-1362$.

Cratty MS, Ward HE, Johnson EA, Azzaro AJ \& Birkle DL 1995 Prenatal stress increases CRF content and release in rat amygdala minces. Brain Research 675 297-302.

Deak T, Nguyen KT, Ehrlich AL, Watkins LR, Spencer RL, Maier SF, Licino J, Wong ML, Chrousos GP, Webster E \& Gold PW 1999 The impact of a nonpeptide corticotropin-releasing hormone antagonist antalarmin on behavioral and endocrine responses to stress. Endocrinology 140 79-86.
Ferin M 1995 The antireproductive role of corticotropin releasing hormone and interleukin-1 in the female rhesus monkey. Annales d'Endocrinologie 56 181-186.

Firn DM, Emanuel RL, Robinson BG, Smas CM, Alder GK \& Majzoub JA 1988 Characterization and gestational regulation of corticotropin releasing hormone messenger RNA in human placenta. Journal of Clinical Investigation 82 287-292.

Goland RS, Wardlaw SL, Blum M, Tropper PJ \& Stark RL 1988 Biologically active corticotropin-releasing hormone in maternal and fetal plasma during pregnancy. Journal of Obstetrics and Gynecology 159 884-890.

Goland RS, Sharon SL, Fortman JD \& Stark RI 1992 Plasma corticotropin releasing hormone factor concentrations in the baboon during pregnancy. Endocrinology 131 1782-1786.

Goland RS, Jozak S, Warren WB, Conwell IM, Stark RI \& Tropper PJ 1993 Elevated levels of umbilical cord plasma corticotropinreleasing hormone in growth-retarded fetuses. Journal of Clinical Endocrinology and Metabolism 77 1174-1179.

Goland RS, Tropper PJ, Warren WB, Stark RI, Jozak SM \& Conwell IM 1995 Concentrations of corticotropin-releasing hormone in the umbilical cord blood of pregnancies complicated by pre-eclampsia. Reproduction, Fertility and Development 7 1227-1230.

Gold PW, Chrousos G, Kellner C, Post R, Roy A, Augerinos P, Schulte H, Oldfield E \& Loriaux DL 1984 Psychiatric implications of basic and clinical studies with corticotropin-releasing hormone. American Journal of Psychiatry 141 619-627.

Gold PW, Goodwin FK \& Chrousos GP 1988 Clinical and biochemical manifestation of depression: relation to the neurobiology of stress. New England Journal of Medicine 319 348-353.

Gray TS \& Birnaman EW 1996 The amygdala: corticotropin releasing hormone, steroids and stress. Critical Reviews in Neurobiology 10 155-168.

Helfer V, Deransart C, Maresc C \& Depaulis A 1996 Amygdala kindling in the rat: anxiogenic-like consequences. Neuroscience $\mathbf{7 3}$ 971-978.

Herbert J 1993 Peptides in the limbic system: neurochemical codes for co-ordinated adaptive responses to behavioural and physiological demand. Progress in Neurobiology 41 723-791.

Herman JP \& Cullian WE 1997 Neurocircuitry of stress: central control of the hypothalamic-pituitary-adrenocortical axis. Trends in Neurosciences 20 78-84.

Hobel CJ, Dunkel-Schetter C, Roesch SC, Castro LC \& Arora CP 1999 Maternal plasma corticotropin-releasing hormone associated with stress at 20 weeks' gestation in pregnancies ending in preterm delivery. American Journal of Obstetrics and Gynecology 180 S257-263.

Imaki T, Nahan JL, Rivierkk C \& Vale W 1991 Differential regulation of corticotropin-releasing hormone mRNA in rat brain regions by glucocorticoids and stress. Journal of Neuroscience $\mathbf{1 1}$ 585-599.

Jones SA, Brooks AN \& Challis JRG 1989 Steroids modulate corticotropin-releasing hormone production in human fetal membranes and placenta. Journal of Clinical Endocrinology and Metabolism 125 2751-2757.

Ju G, Swanson LW \& Simerly RB 1989 Studies on the cellular architecture of the bed nuclei of the stria terminalis in the rat. II Chemoarchitecture. Journal of Comparative Neurology 280 603-621.

Kalin NH, Shelton SE \& Barksdale CM 1989 Behavioral and physiologic effects of corticotropin releasing hormone administered to infant primates undergoing maternal separation. Neuropsychopharmacology 2 97-104.

Kalin NH, Takahashi LK \& Chen FL 1994 Restraint stress increases corticotropin releasing hormone mRNA content in the amygdala and the paraventricular nucleus. Brain Research 656 182-186.

Karalis L, Goodwin G \& Majzoub JA 1996 Cortisol blockade of progesterone: a possible molecular mechanism involved in the initiation of labor. Nature Medicine 2 556-560. 
Kling MA, Rubinow DR, Doram AR, Roy A, Davis CL, Calabrese JR, Nieman LK, Post RM, Chrousos GP \& Gold PW 1993 Cerebrospinal fluid immunoreactive somatostatin concentrations in patients with Cushing's disease and major depression: relationship to indices of corticotropin-releasing hormone and cortisol secretion. Neuroendocrinology 57 79-88.

Kling MA, Glowa JF, Pluznik D, Demas J, DeBellis MD, Gold PW \& Schulkin J 1993 Facilitation of cocaine-kindling by glucocorticoids in rats. Brain Research 372 345-351.

Koob GF 1993 The role of corticotropin-releasing hormone in behavioral responses to stress. In Corticotropin-Releasing Factor. Eds K Chadwick, J Marsh \& K Ackrill. New York: John Wiley and Sons.

Koob GF \& Bloom FE 1985 Corticotropin-releasing factor and behavior. Federation Proceedings 44 259-263.

Korebrits C, Yu DHT, Ramirez MM, Marinoni E, Bocking AD \& Challis JRG 1998 Antenatal glucocorticoid administration increases corticotrophin-releasing hormone $(\mathrm{CRH})$ in maternal plasma. British Journal of Obstetrics and Gynaecology 105 556-561.

Laatikainen T, Virtanen T, Raisanen I \& Salminen K 1987 Immunoreactive corticotropin releasing factor and corticotropin during pregnancy, labor and puerperium. Neuropeptides 10 343-353.

LeDoux JE 1987 Emotion. In Handbook of Physiology. The Nervous System, pp 419-459. Ed ER Kandel. Bethesda, MD: American Physiological Society.

LeDoux JE 1996 The Emotional Brain. New York: Simon and Schuster.

Lee Y \& Davis M 1997 Role of the hippocampus, the bed nucleus of the stria terminalis and the amygdala in the excitatory effect of $\mathrm{CRH}$ on the acoustic startle reflex. Journal of Neuroscience $\mathbf{1 7}$ 6434-6446.

Lee Y, Schulkin J \& Davis M 1994 Effect of corticosterone on the enhanced acoustic startle reflex by corticotropin-releasing factor. Brain Research 666 93-99.

Lefebvre DL, Giaid A \& Zingg HH 1992 Expression of the oxytocin gene in rat placenta. Endocrinology 130 1185-1192.

Lim AT \& Gude NM 1995 Atrial natriuretic factor production by the human placenta. Journal of Clinical Endocrinology and Metabolism $\mathbf{8 0}$ 3091-3093.

Lovenberg TW, Chalmers DT, Liu C \& DeSouza EB 1995 CRF2 beta receptor mRNAs are differentially distributed between the rat central nervous system and peripheral tissues. Endocrinology 136 4139-4142.

McEwen BS 1998 Protective and damaging effects of stress mediators. New England Journal of Medicine 338 171-179.

McEwen BS \& Stellar E 1993 Stress and the individual. Archives of Internal Medicine 153 2093-2101.

MacGregor JA, Jackson GM, Lachelin GC, Goodwin TM, Artal R, Hastings C \& Dullien V 1995 Salivary estriol as risk assessment for preterm labor: a prospective trial. American Journal of Obstetrics and Gynecology 173 1337-1342.

McLean M, Bisits A, Davies J, Woods R, Lowry P \& Smith R 1995 A placental clock controlling the length of human pregnancy. Nature Medicine 1 460-463.

Makino S, Gold PW \& Schulkin J 1994a Effects of corticosterone on CRH mRNA and content in the bed nucleus of the stria terminalis: comparison with the effects in the central nucleus of the amygdala and the paraventricular nucleus of the hypothalamus. Brain Research 657 141-149.

Makino S, Gold PW \& Schulkin J $1994 b$ Corticosterone effects on corticotropin releasing hormone mRNA in the central nucleus and the parvocellular region of the paraventricular nucleus of the hypothalamus. Brain Research 640 105-112.

Marinoni E, Korebrits C, DiIorio R, Cosmi EV \& Challis JRG 1998 Effect of betamethasone in vivo on placental corticotropin-releasing hormone in human pregnancy. American Journal of Obstetrics and Gynecology 178 770-778.

Michelson D, Stratakis C, Hill L, Reynolds J, Galliven E, Chrousos G \& Gold P 1996 Bone mineral density in women with depression. New England Journal of Medicine 335 1176-1181.
Moga MM, Saper CB \& Gray TS 1989 Bed nucleus of the stria terminalis: cytoarchitecture, immunohistochemistry, and projection to the parabrachial nucleus in the rat. Journal of Comparative Neurology 283 315-332.

Munck A, Guyre PM \& Holbrook NJ 1984 Physiological regulation of glucocorticoids in stress and their regulation to pharmacological actions. Endocrine Reviews 5 25-44.

Nappi RE \& Rivier S 1995 Corticotropin-releasing factor (CRF) and stress-related reproductive failure: the brain as a state of the art or the ovary as a novel clue? Journal of Endocrinological Investigation 18 $872-880$.

Nemeroff CB 1992 New vistas in neuropeptide research in neuropsychiatry: focus on corticotropin-releasing factor. Neuropsychopharmacology 6 69-75.

Nemeroff CB, Widerlov E, Bissette G, Walleus H, Karlsson I, Eklund K, Kilts CD, Loosen PT \& Vale W 1984 Elevated concentrations of corticotropin-releasing factor-like immunoreactivity in depressed patients. Science 26 1342-1343.

Patchev RK \& Almeida OF 1996 Gonadal steroids exert facilitating and 'buffering' effects on glucocorticoid-mediated transcriptional regulation of corticotropin-releasing hormone and corticosteroid receptor genes in rat brain. Journal of Neuroscience 16 7077-7084.

Pepe GJ \& Albrecht ED 1995 Actions of placental and fetal adrenal steroid hormones in primate pregnancy. Endocrine Reviews $\mathbf{1 6}$ 608-648.

Petraglia F, Sutton S \& Vale W 1989 Neurotransmitters and peptides modulate the release of immunoreactive corticotropin-releasing factor from cultured human placental cells. American Journal of Obstetrics and Gynecology 160 247-251.

Petraglia F, Volpe A, Genazzani AR, Rivier J, Sawchenko PE \& Vale W 1990a Neuroendocrinology of the human placenta. Frontiers in Neuroendocrinology 11 6-37.

Petraglia F, Vaughan J \& Vale W $1990 b$ Steroid hormones modulate the release of immunoreactive gonadotropin-releasing hormone from cultured human placental cells. Journal of Clinical Endocrinology and Metabolism 70 1173-1178.

Petraglia F, Aguzzoli P, Florio P, Baumann AD, Genazzani C, DiCarlo C \& Romero R 1995 Maternal plasma and placental immunoreactive corticotrophin-releasing factor concentrations in infection-associated term and pre-term delivery. Placenta 16 157-164.

Petraglia F, Florio P, Gallo R, Simoncini T, Saviozzi M, DiBlasio AM, Vaughan J \& Vale W 1996 Human placenta and fetal membranes express human urocortin mRNA and peptide. Journal of Clinical Endocrinology and Metabolism 3806-3810.

Pfaff DW 1980 Estrogens and Brain Function. Berlin: Springer-Verlag.

Pich EM, Koob GF, Heilig M, Menzaghi F, Vale W \& Weiss F 1993a Corticotropin-releasing factor release from the mediobasal hypothalamus of the rat as measured by microdialysis. Neuroscience 55 695-707.

Pich EM, Heinrichs SC, Rivier C, Miczek KA, Fisher DA \& Koob GF $1993 b$ Blockade of pituitary-adrenal axis activation induced by peripheral immunoneutralization of corticotropin-releasing factor does not affect the behavioral response to social defeat stress in rats. Psychoneuroendocrinology 18 495-507.

Potter E, Sutton S, Donaldson C, Chen R, Perrin M, Lewis K, Sawchenko PE \& Vale W 1994 Distribution of corticotropinreleasing factor receptor mRNA expression in the rat brain and pituitary. Proceedings of the National Academy of Sciences of the USA $918777-8781$

Richter CP 1943 Total self-regulatory functions in animals and human beings. Harvey Lecture Series 38 63-103.

Riley SC, Walton JC, Herlick JM \& Challis JRG 1991 The localization and distribution of corticotropin-releasing hormone in the human placenta and fetal membranes throughout gestation. Journal of Clinical Endocrinology and Metabolism 72 1001-1007. 
Robinson BG, Emanuel RI, Friom DM \& Majzoub JA 1988 Glucocorticoid stimulates expression of corticotropin-releasing hormone gene in human placenta. Proceedings of the National Academy of Sciences of the USA 85 5244-5248.

Robinson BG, Arbiser JL, Emanuel RL \& Majzoub JA 1989 Species specific placental corticotropin releasing hormone messenger RNA and peptide expression. Molecular and Cellular Endocrinology 62 337-341.

Rosen JB \& Schulkin J 1998 From normal fear to pathological anxiety. Psychological Review 105 325-350.

Rosen JB, Pishevar SK, Weiss SRB, Smith MA, Gold PW \& Schulkin J 1994 Glucocorticoid potentiation of corticotropin releasing hormone-induced seizures. Neuroscience Letters $\mathbf{1 7 4}$ 113-116.

Sapolsky RM 1992 Stress, The Aging Brain, and the Mechanisms of Neuron Death. Cambridge, MA: MIT Press.

Sasaki A, Liotta AS, Luckey MM, Margioris AN, Suda T \& Krieger D 1984 Immunoreactive corticotropin-releasing factor is present in human maternal plasma during the third trimester of pregnancy. Journal of Clinical Endocrinology and Metabolism 59 812-814.

Sawchenko PE 1987 Evidence for a local site of action for glucocorticoids in inhibiting CRF and vasopressin expression in the paraventricular nucleus. Brain Research 403 213-223.

Sawchenko PE 1993 The functional neuroanatomy of CRF. In Corticotropin Releasing Factor. Eds DJ Chadwick, J Marsh \& K Ackrill. New York: John Wiley and Sons.

Schulkin J 1998 The Neuroendocrine Regulation of Behavior. Cambridge: Cambridge University Press.

Schulkin J, McEwen BS \& Gold P 1994 Allostasis, amygdala, and anticipatory angst. Neuroscience and Biobehavioral Reviews $\mathbf{1 8}$ 385-396.

Schulkin J, Gold P \& McEwen BS 1998 Induction of corticotropin releasing hormone gene expression by glucocorticoids. Psychoneuroendocrinology 23 219-243.

Sheline YI, Wang PW, Gado MH, Csernansky JG \& Vannier MW 1996 Hippocampal atrophy in recurrent major depression. Proceedings of the National Academy of Sciences of the USA 93 3908-3913.

Shibasaki T, Odagiri E, Shizume K \& Ling N 1982 Corticotropinreleasing factor-like activity in human placental extracts. Journal of Clinical Endocrinology and Metabolism 55 384-386.

Smith R, Chan EC, Bowman ME, Harewood WJ \& Phippard AF 1993 Corticotropin releasing hormone in baboon pregnancy. Journal of Clinical Endocrinology and Metabolism 76 1063-1068.

Stenzel-Poore MP, Heinrichs SC, Riverst S, Koob GF \& Vale WW 1994 Overproduction of corticotropin-releasing hormone in transgenic mice: a genetic model of anxiogenic behavior. Journal of Neurosience 14 2579-2584.

Sterling P \& Eyer J 1988 Allostasis: a new paradigm to explain arousal pathology. In Handbook of Stress, Cognition and Health. Eds S Fisher \& J Reason. New York: John Wiley and Sons.

Swanson LW \& Simmons DM 1989 Differential steroid hormone and neural influences on peptide mRNA levels in corticotropinreleasing hormone cells of the paraventricular nucleus: a hybridization histochemical study in the rat. Journal of Comparative Neurology 285 413-435.

Swanson LW, Sawchenko PE, Rivier J \& Vale WW 1983 Organization of ovine corticotropin releasing hormone immunoreactive cells and fibers in the rat brain: an immunohistochemical study. Neuroendocrinology 36 165-186.

Swerdlow NR, Britton KT \& Koob GF 1989 Potentiation of acoustic startle by corticotropin-releasing factor (CRF) and by fear are both reversed by alpha-helical CRF(9-41). Neuropsychopharmacology 2 285-292.

Taniguchi T, Matsuzaki N, Kameda T, Shimoya K, Jo T, Saji F \& Tanizawa O 1991 The enhanced production of placental interleukin-1 during labor and intrauterine infection. American Journal of Obstetrics and Gynecology 165 131-137.

Tanimura SM \& Watts AG 1998 Corticosterone can facilitate as well as inhibit corticotropin releasing hormone gene expression in the rat hypothalamic paraventricular nucleus. Endocrinology 139 3830-3836.

Tropper PJ, Goland RS, Wardlaw SL, Fox HE \& Frants AG 1987 Effects of betamethasone on maternal plasma corticotropin releasing factor, ACTH and cortisol during pregnancy. Journal of Perinatal Medicine 15 221-224.

Vale W, Spiess J, Rivier C \& Rivier J 1981 Characterization of a 41-residue ovine hypothalamic peptide that stimulates secretion of corticotropin and beta-endorphin. Science 213 1394-1397.

Valentino RJ, Page ME, Van Bockstaele E \& Aston-Jones G 1992 Corticotropin releasing factor immunoreactive cells and fibers in the locus coeruleus region: distribution and sources of input. Neuroscience 48 689-705.

Warren WB, Patrick SL \& Goland RS 1992 Elevated maternal plasma corticotropin-releasing hormone levels in pregnancies complicated by preterm labor. American Journal of Obstetrics and Gynecology 166 1198-1204.

Wasser SK 1996 Reproductive control in wild baboons measured by fecal steroid. Biology of Reproduction 55 393-399.

Watts AG 1996 The impact of physiological stimuli on the expression of corticotropin releasing hormone and other neuropeptide genes. Frontiers in Neuroendocrinology 17 281-326.

Watts AG \& Sanchez-Watts G 1995 Region specific regulation of neuropeptide mRNAs in rat limbic forebrain neurones by aldosterone and corticosterone. Journal of Physiology 484 721-736.

Weinstock M 1996 Does prenatal stress impair coping and regulation of hypothalamic-pituitary-adrenal axis? Neuroscience and Biobehavioral Reviews 21 1-10.

Weiss SR, Post RM, Gold PW, Chrousos G, Sullivan TL, Walker D \& Pert A 1986 Corticotropin releasing hormone-induced seizures and behavior: interaction with amygdala kindling. Brain Research 372 345-351.

Williams MT, Hennessy MB \& Davis HN 1995 Corticotropin releasing hormone administered to pregnant rats alters offspring behavior and morphology. Pharmacology, Biochemistry and Behaviour 52 161-167.

Wolfe CDA, Patel SP, Campbell EA, Linton EA, Anderson J, Lowry PJ \& Jones MT 1988a Plasma corticotrophin-releasing factor (CRF) in normal pregnancy. British Journal of Obstetrics and Gynaecology 95 997-1002.

Wolfe CDA, Patel SP, Linton EA, Campbell EA, Anderson J, Dornhorst A, Lowry PJ \& Jones MT 1988b Plasma corticotrophinreleasing factor (CRF) in abnormal pregnancy. British Journal of Obstetrics and Gynaecology 95 1003-1006.

Wu WX, Unno S, Giussani DA, Mecenas CA, McDonald TJ \& Nathanielsz PW 1995 Corticotropin releasing hormone and its receptor distribution in fetal membranes and placenta of the rhesus monkey in late gestation and labor. Endocrinology 136 4621-4628.

Received 7 July 1998

Revised manuscript received 14 September 1998 Accepted 3 November 1998 